\title{
How To Build Continuance Intention On Jenius App Users
}

\author{
Tri Wahyu Oktavendi ${ }^{\text {a }}$ iD, Ike Arisanti a 1 iD \\ ${ }^{a}$ Faculty of Economics and Business, University of Muhammadiyah Malang, Indonesia
}

\section{APA Citation:}

Oktavendi, T.W., \& Arisanti, I. (2021). How to build continuance intention on jenius app users. TIJAB (The International Journal of Applied Business), 5(2), 155-165.

Submission Date: 07/09/2021

Acceptance Date: 07/11/2021

\begin{abstract}
The availability of various kinds of transaction services via smartphones will certainly affect its users. The theme of Financial Technology (Fintech) is also developing which includes transactions through smartphone applications. The big question arises, namely what are the factors that influence Jenius-App users to be intense in using the application? Its Benefit? Or its Risk?. This study tries to examine the factors that affect Continuance Intention on Jenius App users. Smart PLS 15 is used in this study by using Outer Model and Inner Model. The Results show that it is only three hypotheses are accepted. First, Perceived Usefulness Affect on Continuance Intention. Second, Perceived Ease of Use Affect on Perceived Usefulness. Third, Perceived Risk Affect on Perceived Ease of Use.
\end{abstract}

Keywords: continuance intention; jenius app; risk; technology adoption; smart financial transaction

This is an open access article under the CC BY-NC-SA license.

\section{Introduction}

The development of transaction technology is growing rapidly. The availability of various kinds of transaction services via smartphones will certainly affect its users. The theme of Financial Technology (Fintech) is also developing which includes transactions through smartphone applications. This is an innovation in financial transaction activities. The innovation started with the fusion of financial services and information technology. Based on data presented by financial institutions, it shows that the number of Fintech companies legally registered in Indonesia is 144 as of October 2019 (ojk.go.id). Choi and Choi (2017) state that financial transaction services by smartphone are an alternative to cash and credit card transactions which certainly provide convenience and speed. It is also very meaningful for users to save time and maintain clear transaction records. This is an advantage for both users and service providers. These advantages have greatly expanded the global mobile payments market and brought great changes not only in the financial sector but also in the mobile industry.

\footnotetext{
${ }^{1}$ Corresponding author.

E-mail address: ikearisanti@umm.ac.id
} 
In the banking sector, transactions that have adopted smartphone technology are internet banking, sms banking, and mobile banking. E-Banking is proven to make it easier for users because users can make transactions anytime and anywhere as long as they are connected to the internet and mobile phones. Another banking product is M-Banking, which certainly provides more services than EBanking. M-Banking is a financial transaction application available on smartphones. The emergence of this innovation is expected to be one of the improvements in service to customers. Technology continues to develop, until now one of the banks in Indonesia, namely BTPN, innovates to create a service known as Jenius-App. This application provides more benefits, such as transactions in foreign currencies, as a financial manager, as a credit card, and even a split-bill feature (to split the bill when eating together). The big question arises, namely what are the factors that influence Jenius-App users to be intense in using the application? Its Benefit? Or its Risk?

In Indonesia, there are several studies related to Jenius App, including Teja (2017) which examines what factors are the keys to the success of mobile payments in Indonesia. Nawangsari and Iswah (2019) examined the perceptions and benefits of using Jenius satisfaction. Al Attas and Rachmawati (2019) examined the technology acceptance model in Jenius applications. From previous research, there are many factors on acceptance model. In this research, TAM and Risk are used to explain the phenomena, because the previous research is only using TAM (benefit perspectives) without risk perspectives.

\section{Literature Review}

\subsection{Technology Acceptance Model}

The TAM method was first introduced by Davis (1989). TAM is an information systems theory that makes a model of the process by which users are willing to accept and use technology. This model explains that when users use information systems, a number of factors influence their decisions about how and when to use the information site. The TAM model was adopted from The Theory of Reasoned Action (TRA) model, namely the theory of reasoned action developed by Ajzen and Fishbein (1975), with the premise that a person's reaction and perception of something will determine that person's attitude and behavior. This theory makes a model of a person's behavior as a function of behavioral goals. The purpose of the behavior is determined by the attitude towards the behavior. Can Key reactions and perceptions of IT users will affect their attitude in accepting the use of IT, one of the influencing factors is the user's perception of the usefulness and ease of use of IT as an action that makes sense in the context of using IT, therefore the reason someone sees the benefits and convenience the use of IT makes the person's actions acceptable to the use of IT. The main purpose of TAM is to become the basis for understanding the influence of external factors on internal beliefs and attitudes. TAM achieves the above objectives by identifying several fundamental variables in accordance with the results of previous studies on the determinants of computer acceptance. In this study, we try to explore the factors that influence Jenius App users to continue using Jenius-App. Therefore, the factors used are Perceived Ease of use, Perceived Usefulness, Risk and Continuance Intention.

\subsection{Perceived Usefulness}

Perceived Usefulness is defined by Davis (1989) as a level or state where a person believes that using a particular system will improve his performance. Perceived usefulness is a level where a person believes that the user of a particular system will improve that person's work performance. Based on this definition, it means that the benefits of using ICT can improve performance, work performance of people who use it. Thompson, Higgins, and Howell (1991) concluded that the benefits of information technology are the benefits expected by users of information technology to carry out their duties. Thompson et al. (1991) also states that an individual will use ICT if the person knows the benefits or 
uses have a positive effect on its use. The benefits felt by these users will affect the intensity (Joo, So, and Kim, 2018; Bai, Wang, and Chai, 2019; Jo, 2021) in using the Jenius.

H1: Perceived Usefulness Affect Continuance Intention.

\subsection{Perceived Ease of Use}

According to Davis (1989) Perceived Ease of Use is defined as a level or state where a person believes that using a particular system reduces effort or even no effort is required. According to Goodwin (1987) and Silver (1988) the intensity of use and interaction between the user (user) and the system can indicate the level of ease of use. The findings of the Igbaria (1994) prove that IT is not used absolutely because of social pressure, so it can be concluded that the use of IT is not because of the element of pressure, but because it is easy to use. Perceived ease of use is a factor that influences continuance intention, some previous research show results that Perceived Ease of Use affect Perceived Usefulness. In addition, previous research also found that Perceived Usefulness has an impact on Continuance Intention (Joo, So, and Kim, 2018; Bai, Wang, and Chai, 2019; Jo, 2021).

H2: Perceived Ease of Use Affect Perceived Usefulness.

H3: Perceived Ease of Use Affect Continuance Intention

\subsection{Perceived Risk}

Research conducted by Hossain, Islam, Khan, and Ramayah (2011) shows that there are factors that influence the use of Mobile Commerce services, namely Security and Privacy Risks. The results of research by Arief (2021) prove that there is a positive influence between risk and intention to use Electronic Commerce services. Risk will reduce user interest in reusing a new technology. Risks in digital finance vary widely, one example is the risk of cybercrime (Muzdalifa, Rahma, \& Novalia, 2018). On the other hand, Dwitasari and Baridwan (2014) showed different results. The results of his research stated that the perception of risk did not affect a person's interest in using Mobile Commerce services. This is supported by research by Saraswati and Baridwan (2013) which focuses on Electronic Commerce. The difference in the results of previous studies raises the potential for a new model, that in fact the Risk will on Perceived Usefulness and Perceived Ease of Use.

H4: Perceived Risk Affect Perceived Usefulness.

H5: Perceived Risk Affect Perceived Ease of Use.

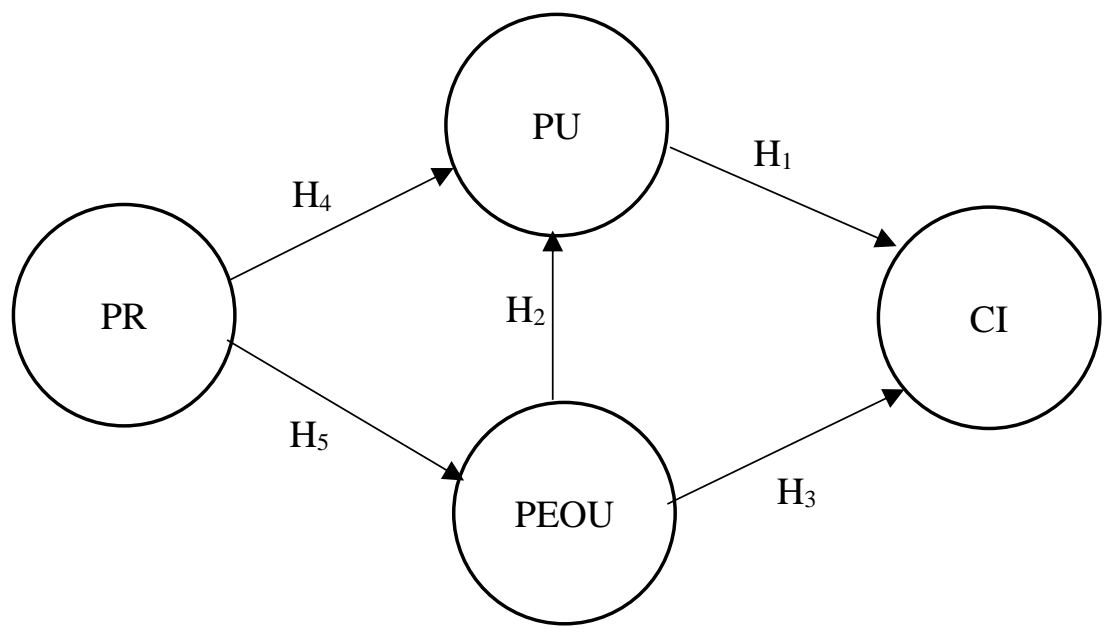

Figure 1. Research framework 


\section{Method}

\section{1. $\quad$ Sample / Participants}

This study tries to examine the factors that affect Continuance Intention on Jenius App users. Therefore, the participants in this study were Jenius App users. Based on the results of data collection, the number of participants that can be collected is 54 Jenius App users from 103 total participant. The descriptions of participant are presented in table 1.

Table 1. Participant descriptions

\begin{tabular}{lccc}
\hline & \multicolumn{2}{c}{ Characteristics N=103 } & \\
\hline Variabel & Descriptions & Frequency & Percentage (\%) \\
Respondent & Total of Respondent & 103 & $100 \%$ \\
& Non-Jenius App User & 49 & $48 \%$ \\
& Jenius App User & 54 & $52 \%$ \\
Gender of & Male & 16 & $32 \%$ \\
Jenius App User & Female & 38 & $68 \%$ \\
Age of & $20-30$ y/o & 41 & $76 \%$ \\
Jenius App User & $31-40$ y/o & 11 & $20 \%$ \\
& $41-50$ y/o & 1 & $2 \%$ \\
& $51-60$ y/o & 1 & $2 \%$ \\
Last education of & $>60$ y/o & 0 & $0 \%$ \\
Jenius App User & High School & 10 & $19 \%$ \\
& Bachelor (S1) & 30 & $55 \%$ \\
& Magister (S2) & 13 & $24 \%$ \\
& Doctor (S3) & 1 & $2 \%$ \\
\hline
\end{tabular}

\subsection{Instrument $(s)$}

Continuance Intention in this study uses the instrument used by Bhattacherjee (2001) and Hsiao, Chang, and Tang (2016). There are three question items for the continuance intention factor, while for Perceived Usefulness and Perceived Ease of Use there are four question items each. The question items adopted the question instrument developed by Davis (1989). The question instrument for Perceived Risk is three questions. The instrument used is an instrument developed by Liébana-Cabanillas, Molinillo, and Ruiz-Montañez (2019).

Table 2. Research instruments

\begin{tabular}{|c|c|c|}
\hline \multicolumn{3}{|l|}{ Risk } \\
\hline PR1 & Using Jenius-App makes me feel anxious & $\begin{array}{l}\text { Liébana-Cabanillas et al. } \\
\text { (2014) }\end{array}$ \\
\hline PR2 & $\begin{array}{l}\text { My time is wasted just for using the Jenius- } \\
\text { App }\end{array}$ & \\
\hline PR3 & $\begin{array}{l}\text { There was a waste of time during activation } \\
\text { and learning how to use Jenius-App }\end{array}$ & \\
\hline \multicolumn{3}{|c|}{ Perceived Ease of Use } \\
\hline PE1 & $\begin{array}{l}\text { Jenius-App is easy to download on the } \\
\text { appstore / playstore. }\end{array}$ & Davis (1989) \\
\hline PE2 & $\begin{array}{l}\text { The Jenius-App registration process is easy } \\
\text { and takes a short time }\end{array}$ & \\
\hline PE3 & $\begin{array}{l}\text { It is very easy for me to complete a } \\
\text { transaction on Jenius-App }\end{array}$ & \\
\hline
\end{tabular}


PE4

Perceived Usefulness

PU1

PU2

PU3

PU4

Continuance Intention

CI1

CI2

CI3
I believe that it is very easy to learn to apply

Jenius-App without taking a long time

I can use Jenius-App anytime and anywhere, which means it is very useful for me Jenius-App makes it easy for me to transact and manage finances

I believe that using Jenius-App will make it easier for me to understand information Jenius-App makes it easy for me to get information about transactions and financial management

I intend to continue using Jenius-App in the future

Bhattacherjee (2001)

I will use Jenius-App in my daily life

I will continue to use Jenius-App regularly as I do now

\subsection{Data collection procedures}

The data collected in this study is the data from the questionnaire. The questionnaires that have been compiled are distributed to Jenius App users with the help of Social Media and WhatsApp Groups. Not only that, the researcher also asked colleagues who work at BTPN to help distribute the questionnaires. The questionnaire was distributed via Google form Link.

\subsection{Data analysis}

Researchers arrange the stages of data analysis as follows:

1. Questionnaire data are tabulated.

2. Testing the Outer Model.

Outer Model testing includes reliability and validity tests. The reliability test in this study used Cronbach's Alpha. Cronbach's Alpha value must have a minimum magnitude of 0.7. Cronbach's Alpha should ideally be rated 0.8 to 0.9. Reliability is also seen from the value of Average Variance Extracted (AVE). The AVE result must be $>0.7$ to be reliable and $>0.5$ to convergent validity. Reflective indicators also need to be tested for discriminant validity by looking at the cross loading.

\section{Testing the Inner Model}

The Inner Model is also known as the structural model. To test the Inner Model, researchers looked at the value of R2 with the following criteria:

a. The $\mathrm{R} 2$ value of 0.67 is categorized as substantial,

b. R2 value of 0.33 is categorized as moderate,

c. R2 value of 0.19 is categorized as weak

d. R2 value of $>0.7$ is categorized as strong

4. Doing Hypothesis Testing

Hypothesis testing in this study by looking at the value of t-count and $\mathrm{p}$-value. The results of the study are said to be influential if the t-count value is $>1.96$ and the $p$-value is $<0.005$. 


\section{Results}

\subsection{Outer Model Test}

In the Outer Model Test, researchers measure the reliability and validity of the measurement model in this study. First, the reliability test is carried out by looking at the Composite Reliability value. If the Compositor Reliability value is above 0.7 then it is declared Reliable. In Table 3 , it can be concluded that each variable is declared reliable with a CI value of 0.973 , PEOU of 0.904 , PU of 0.932 , and PR of 0.956. Second, to test the validity of this study, namely Convergent Validity and Discriminant Validity. Convergent Validity Testing can be done by looking at the Average Variance Extracted (AVE) value. The AVE value must be at least greater than 0.5 to meet Convergent Validity. Table 2 shows the AVE value above 0.5 , meaning that all variable measurements are declared valid.

Table 3. Reliability and validity test results

\begin{tabular}{lrrrr}
\hline & Cronbach's Alpha & rho_A & $\begin{array}{l}\text { Composite } \\
\text { Reliability }\end{array}$ & $\begin{array}{l}\text { Average } \\
\text { Variance } \\
\text { Extracted } \\
\text { (AVE) }\end{array}$ \\
\hline CI & & & \multicolumn{2}{c}{0.922} \\
PEOU & 0.958 & 0.960 & 0.973 & 0.704 \\
PU & 0.858 & 0.885 & 0.904 & 0.775 \\
PR & 0.904 & 0.919 & 0.932 & 0.879 \\
\hline
\end{tabular}

On the other hand, Discriminant Validity is done by looking at the Cross Loading value. In this study, the reference value used is above 0.7. It can be seen in Table 4 that all cross-loading values (pink) for each indicator are above 0.7 . In addition, the discriminant validity test can be seen from the cross-loading indicator value of a construct which is greater than the cross-loading indicator value of the construct to other constructs. In table 3 it can be seen that the cross-loading value of the indicator of a construct is greater than the value of the cross loading of the construct indicator against other constructs, then the discriminant validity of each indicator on the variable has been met.

Table 4. Cross loading

\begin{tabular}{lrrrr}
\hline & \multicolumn{1}{l}{ CI } & \multicolumn{1}{l}{ PEOU } & \multicolumn{2}{l}{ PU } \\
\hline (CI1) & 0.958 & 0.655 & 0.723 & -0.392 \\
$(\mathrm{CI})$ & 0.972 & 0.587 & 0.775 & -0.329 \\
$(\mathrm{CI})$ & 0.951 & 0.532 & 0.702 & -0.308 \\
(PEOU1) & 0.493 & 0.828 & 0.555 & -0.507 \\
(PEOU2) & 0.355 & 0.710 & 0.460 & -0.316 \\
(PEOU3) & 0.642 & 0.922 & 0.719 & -0.438 \\
(PEOU4) & 0.537 & 0.882 & 0.689 & -0.407 \\
(PU1) & 0.767 & 0.671 & 0.832 & -0.294 \\
(PU2) & 0.752 & 0.742 & 0.933 & -0.368 \\
(PU3) & 0.598 & 0.626 & 0.909 & -0.323 \\
(PU4) & 0.520 & 0.496 & 0.844 & -0.325 \\
(PR1) & -0.318 & -0.382 & -0.349 & 0.931
\end{tabular}




$\begin{array}{lllll}\text { (PR2) } & -0.242 & -0.418 & -0.294 & 0.931 \\ \text { (PR3) } & -0.418 & -0.572 & -0.391 & 0.951\end{array}$

\subsection{Inner Model Test}

The Inner Model in PLS is also known as the structural model. Structural model is a model that tries to relate latent variables. The inner model is evaluated using R-Squares for the dependent variable. Changes in the value of R-Square can be used to assess the effect of certain independent latent variables on the dependent latent variable. The results of the R-Square value in this study can be seen in Table 5 . Based on Table 5, the R-Square value for the CI construct is 0.592 , PEOU is 0.250 , and PU is 0.538 . This value indicates that CI can be explained by PEOU and PU by $59.2 \%$ while PEOU is influenced by PR by $25 \%$, and PU is influenced by PR and PEOU by $53.8 \%$, the rest is influenced by other constructs not included in the research model used in this study.

Table 5. R2 and adjusted R2

\begin{tabular}{lll}
\hline & R Square & $\begin{array}{l}\text { R Square } \\
\text { Adjusted }\end{array}$ \\
\hline Continuance Intention & 0.592 & 0.576 \\
PEOU & 0.250 & 0.236 \\
PU & 0.538 & 0.520 \\
\hline
\end{tabular}

The inner model can also be evaluated using a t-test with a significance level of 0.05 (t-statistic $>t$ table). The t-test is used for hypothesis testing which is carried out through the bootstrapping procedure in the SmartPLS program. The significance level used is $95 \%(\alpha=00.05)$ with a t-table of 1.96 . If the $t-$ statistic value is less than 1.96, then the hypothesis is rejected. In Table 6 it can be seen the results of the path coefficient and t-statistics on the inner model. These results indicate that only three hypotheses are accepted, while the other hypotheses are rejected/declined.

Table 6. Hypotheses testing results

\begin{tabular}{lrrrrrr}
\hline & $\begin{array}{l}\text { Original } \\
\text { Sample } \\
(\mathrm{O})\end{array}$ & $\begin{array}{l}\text { Sample } \\
\text { Mean } \\
(\mathrm{M})\end{array}$ & $\begin{array}{l}\text { Standard } \\
\text { Deviation } \\
(\mathrm{STDEV})\end{array}$ & $\begin{array}{l}\text { T Statistics } \\
(|\mathrm{O} / \mathrm{STDEV}|)\end{array}$ & P Values & Decision \\
\hline PEOU -> CI & 0.121 & 0.113 & 0.125 & 0.966 & 0.334 & Declined \\
\hline PEOU -> PU & 0.729 & 0.725 & 0.091 & 7.994 & 0.000 & Accepted \\
\hline PU -> CI & 0.677 & 0.691 & 0.131 & 5.176 & 0.000 & Accepted \\
\hline PR -> PEOU & -0.500 & -0.516 & 0.122 & 4.097 & 0.000 & Accepted \\
\hline PR -> PU & -0.008 & -0.016 & 0.108 & 0.070 & 0.944 & Declined \\
\hline
\end{tabular}




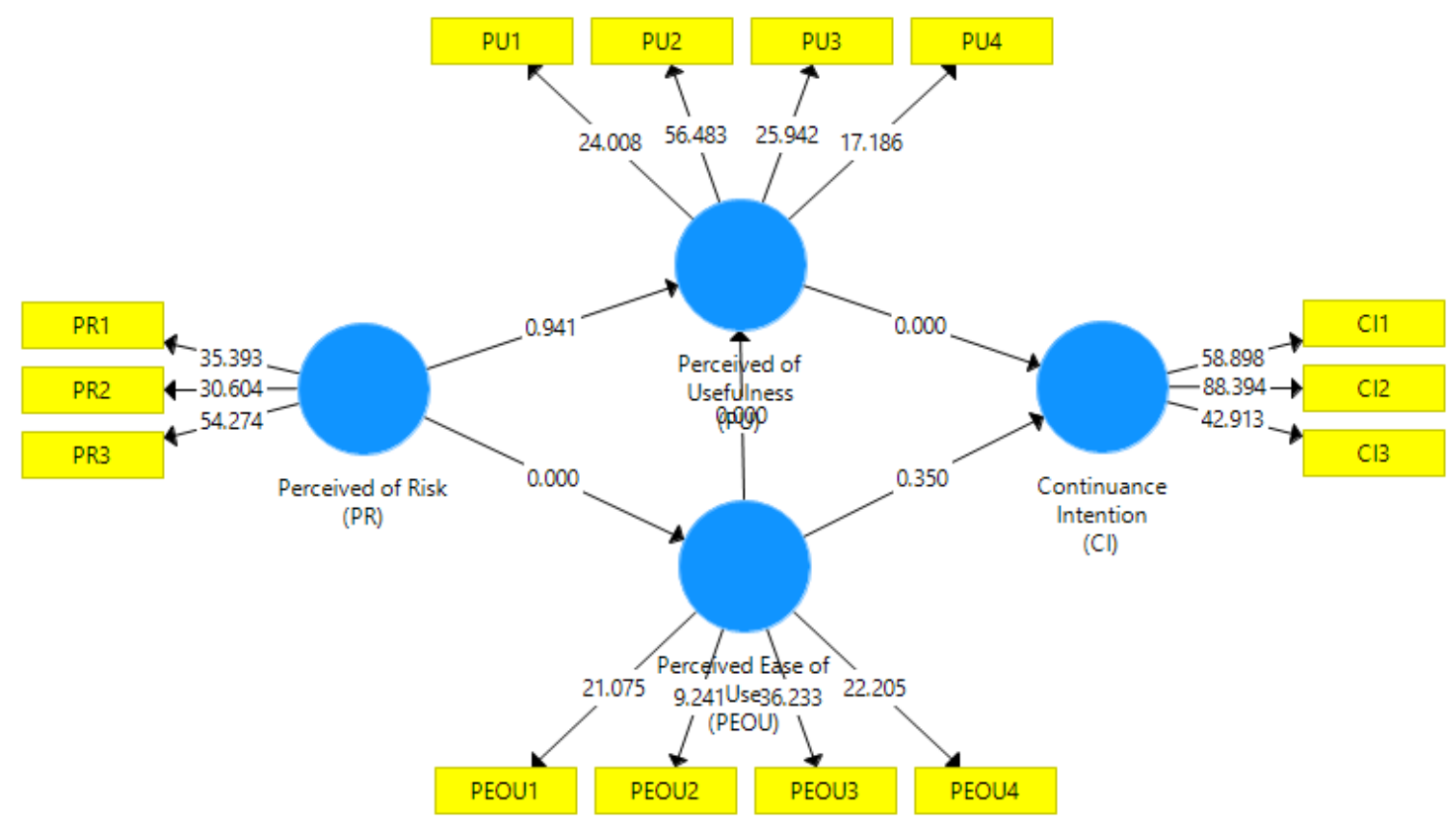

\section{Discussion}

The perceived risk is the main obstacle for Jenius-App users when considering the use of JeniusApp, including financial risk referring to potential financial losses in financial transactions. Legal risk refers to the uncertain legal status and inadequate regulation of FinTech. Security risk is defined as the potential loss from fraud or hacking during financial transactions on Jenius-App, conceptualized as a breach of privacy, which has received great attention from users. Operational risk is an obstacle for users which refers to potential losses due to system failures within the company, caused by the lack of quality of the FinTech system and the employees who run the company. Financial risk refers to the potential financial loss in a financial transaction.

A study in the information systems literature found that perceived financial risk was the most consistent predictor of online and mobile service user behavior (Abramova \& Böhme, 2016). Financial losses caused by FinTech services are caused by malfunctioning financial transaction systems, financial fraud, and additional transaction fees (Zavolokina, Dolata, \& Schwabe, 2016). In this study, the main risks that occur are related to security risk and financial risk will affect the perceived ease of use because there will be less cyber security and financial security, people will find it easier to use the genius app. Saver application does not always require many steps to open or use the application, for example, genius applications, people find it easier to use the application without having to go through many steps except at the beginning of registration.

According to Stewart and Jürjens (2018) data security is a factor that empirically affects FinTech users and companies. Today, digital security is the biggest problem. According to Pinochet, Diogo, Lopes, Herrero, and Bueno (2019), privacy is the most important thing for internet users, therefore creating a security system is very important. Consumers are constantly worried about personal data and information and how it will be used. The use of FinTech is associated with a fairly high potential for losses. Security risk affects users in using FinTech services because the risk perceived by users is quite high

Perceived ease of use was found to have no significant direct effect on continuance intention. This result reflects that users will not continue to use Jenius-app only because it is easy to use but will also 
see other factors including security risks. Since users become more and more familiar with the operation of Jenius-App after initial adoption, whether the Jenius-App platform is easy to use or not is no longer the focus of their attention. Even if the provider upgrades the system, the user will not be likely to discontinue use for this reason. Therefore, the ease of use to continue the intended use is not significant. that the app's easy-to-use genius system is unimportant, because perceived usability is significantly affected by perceived ease of use. Due to mobile network constraints, users may find it difficult to operate banking (Zhou, 2013) and may spend more time and effort on app genius transactions, which will reduce their perception of usability.

However, the results in our study show that Perceived Ease of Use Affect Usefulness (accepted) and Perceived usefulness effect on continuance intention to use Jenius-App (accepted). Perceived technology-task suitability strongly influences perceived usefulness and continuity of intent. If users feel that the Jenius-App service is not suitable for their task, they will consider this service to be of low use and low intent to continue using it. Thus, banks in this case as Jenius-App service providers can adhere to user-centered principles when providing Jenius-App services, to better meet user needs.

Thus, Jenius-App service providers need to improve information security technology, provide warranty statements, help desks, and certificates, etc., to reduce user perceptions of risk. In line with the research of Yuan, Liu, Yao, and Liu (2016) who conducted a research on users' continuance intention in China. First, the results show that perceived risk is the strongest predictor of user continuation intention, followed by satisfaction, task-technology fit, and perceived usefulness. Thus, ensuring the security of fintech services, services are very important for banks to increase user satisfaction, and thus shape their intention to continue using. Second, found that perceived task-technology fit had a significant effect on perceived usefulness and continuance. This suggests that banking service providers need to separate markets and provide personalized services for different user groups. Third, the significant relationship between perceived ease of use and perceived usefulness indicates that it is necessary for banks to present user-friendly and easy-to-use fintech services.

\section{Conclusions}

This research proves that the risks that will be faced by Jenius-App users are a separate consideration for continuing to use the application. In addition, the convenience and usefulness of the Jenius App also supports users to continue using the financial-based application. The convenience felt by users will provide its own benefits for users when carrying out their daily activities. This study has limitations, namely very small respondents due to the difficulty of getting Jenius App users to fill out questionnaires. Further researchers can add several factors that might be included in the model to see the R2 results that are not optimal. This research has an impact on policy for policy makers to consider the factors that exist in this research in making policies.

\section{References}

Abramova, S., \& Böhme, R. (2016). Perceived benefit and risk as multidimensional determinants of bitcoin use: A quantitative exploratory study.

Ajzen, I., \& Fishbein, M. (1975). A Bayesian analysis of attribution processes. Psychological bulletin, 82(2), 261.

Al Attas, W., \& Rachmawati, I. (2019). Factors Affecting the Adoption of Jenius n Indonesia Based on The Unified Theory Of Acceptance And Use Of Technology Model Modified By The Technology Acceptance Model Concept. eProceedings of Management, 6(2). 
Arief, M. (2021). Marketing Analysis: Security and Public Trust Online Shopping at Shopee. co. id. Enrichment: Journal of Management, 11(2), 345-352.

Bai, B., Wang, J., \& Chai, C. S. (2019). Understanding Hong Kong primary school English teachers' continuance intention to teach with ICT. Computer Assisted Language Learning, 1-23.

Bhattacherjee, A. (2001). Understanding information systems continuance: an expectation-confirmation model. MIS quarterly, 351-370.

Choi, Y., \& Choi, H. (2017). Risk Factors Affecting Trust and Satisfaction in Mobile Payment Systems. International Information Institute (Tokyo). Information, 20(8A), 5527-5532.

Davis, F. D. (1989). Perceived usefulness, perceived ease of use, and user acceptance of information technology. MIS quarterly, 319-340.

Dwitasari, M., \& Baridwan, Z. (2014). Faktor Determinan Minat Individu Menggunakan: MCommerce.

Goodwin, N. C. (1987). Functionality and usability. Communications of the ACM, 30(3), 229-233.

Hossain, M. M., Islam, M., Khan, M., \& Ramayah, T. (2011). The adoption of mobile commerce service among employed mobile phone users in Bangladesh: self-efficacy as a moderator.

Hsiao, C.-H., Chang, J.-J., \& Tang, K.-Y. (2016). Exploring the influential factors in continuance usage of mobile social Apps: Satisfaction, habit, and customer value perspectives. Telematics and Informatics, 33(2), 342-355.

Igbaria, M. (1994). An examination of the factors contributing to microcomputer technology acceptance. Accounting, Management and Information Technologies, 4(4), 205-224.

Jo, H. (2021). Understanding the key antecedents of users' continuance intention in the context of smart factory. Technology Analysis \& Strategic Management, 1-14.

Joo, Y. J., So, H. J., \& Kim, N. H. (2018). Examination of relationships among students' selfdetermination, technology acceptance, satisfaction, and continuance intention to use K-MOOCs. Computers \& Education, 122, 260-272.

Liébana-Cabanillas, F., Molinillo, S., \& Ruiz-Montañez, M. (2019). To use or not to use, that is the question: Analysis of the determining factors for using NFC mobile payment systems in public transportation. Technological Forecasting and Social Change, 139, 266-276.

Muzdalifa, I., Rahma, I. A., \& Novalia, B. G. (2018). Peran Fintech Dalam Meningkatkan Keuangan Inklusif Pada UMKM di Indonesia (Pendekatan Keuangan Syariah). Jurnal Masharif al-Syariah: Jurnal Ekonomi dan Perbankan Syariah, 3(1).

Nawangsari, S., \& Iswah, S. N. (2019). Pengaruh Teknologi Informasi, Persepsi Manfaat, Persepsi Kemudahan dan Fitur Layanan Terhadap Kepuasan Nasabah serta Implikasinya pada Minat Ulang Penggunaan Aplikasi Jenius Bank BTPN. Paper presented at the SEMINAR NASIONAL APTIKOM (SEMNASTIK) 2019.

Pinochet, L. H. C., Diogo, G. T., Lopes, E. L., Herrero, E., \& Bueno, R. L. P. (2019). Propensity of contracting loans services from FinTech's in Brazil. International Journal of Bank Marketing.

Saraswati, P., \& Baridwan, Z. (2013). Penerimaan Sistem E-Commerce: Pengaruh Kepercayaan. Persepsi Manfaat dan Persepsi Risiko.

Silver, M. S. (1988). User perceptions of decision support system restrictiveness: An experiment. Journal of Management Information Systems, 5(1), 51-65. 
Stewart, H., \& Jürjens, J. (2018). Data security and consumer trust in FinTech innovation in Germany. Information \& Computer Security.

Teja, A. (2017). Indonesian FinTech business: New innovations or foster and collaborate in business ecosystems? The Asian Journal of Technology Management, 10(1), 10.

Thompson, R. L., Higgins, C. A., \& Howell, J. M. (1991). Personal computing: Toward a conceptual model of utilization. MIS quarterly, 125-143.

Yuan, S., Liu, Y., Yao, R., \& Liu, J. (2016). An investigation of users' continuance intention towards mobile banking in China. Information Development, 32(1), 20-34.

Zavolokina, L., Dolata, M., \& Schwabe, G. (2016). FinTech transformation: How IT-enabled innovations shape the financial sector. Paper presented at the FinanceCom 2016.

Zhou, T. (2013). An empirical examination of continuance intention of mobile payment services. Decision support systems, 54(2), 1085-1091.

\title{
Cara Membangun Continuance Intention Pada Pengguna Jenius App
}

\begin{abstract}
Abstrak
Tersedianya berbagai macam layanan transaksi melalui smartphone tentunya akan mempengaruhi penggunanya. Tema Financial Technology (Fintech) juga berkembang yang mencakup transaksi melalui aplikasi smartphone. Timbul pertanyaan besar, yaitu faktor apa saja yang mempengaruhi pengguna Jenius-App untuk intens menggunakan aplikasi? Manfaatnya? Atau Risikonya?. Penelitian ini mencoba mengkaji faktor-faktor yang mempengaruhi Continuance Intention pada pengguna Jenius App. Smart PLS 15 digunakan dalam penelitian ini dengan menggunakan Outer Model dan Inner Model. Hasil penelitian menunjukkan bahwa hanya tiga hipotesis yang diterima. Pertama, Perceived Usefulness Berpengaruh terhadap Continuance Intention. Kedua, Perceived Ease of Use Mempengaruhi Perceived Usefulness. Ketiga, Perceived Risk Mempengaruhi Perceived Ease of Use.
\end{abstract}

Kata kunci: niat berkelanjutan, aplikasi jenius, resiko, adopsi teknologi, smart financial transaction 